(C) 2001 The Chemical Society of Japan

層状複水酸化物によるベンジルアルコールのベンジル化反応

(2000 年 9 月 14 日受理)

島田 紘*.笹ノ間隆

$\mathrm{CO}_{3}{ }^{2-}$ あるいは $\mathrm{Cl}^{-}$を層間イオンとする $\mathrm{Li}^{+}-\mathrm{Al}^{3+}$ 系の層状複水酸化物 (以下, $\mathrm{LDH}$ と略記する.) が，トルエン中でのベンジルアルコールの臭化ベンジルによるベンジル化を著しく促進することが示さ れた．例えば， $200{ }^{\circ} \mathrm{C}$ で加熱処理した $\mathrm{CO}_{3}{ }^{2-}$ 系を用いた反応では， 6 時間の反応でベンジル化生成物 のジベンジルエーテルが $93 \%$ の高収率で得られた． $\mathrm{Cl}^{-}$系では， $150{ }^{\circ} \mathrm{C} て ゙$ 加熱処理したものを用いた 際に同様の反応時間で $78 \%$ の収率を示した。一方, $\mathrm{Mg}^{2+}-\mathrm{Al}^{3+} \mathrm{LDH}$ の反応促進効果は, $\mathrm{Li}^{+}-\mathrm{Al}^{3+}$ $\mathrm{LDH}$ に比べると小さい. $\mathrm{CO}_{3}{ }^{2-}$ 系を用いた際のジベンジルエーテル収率は, $250{ }^{\circ} \mathrm{C}$ で処理したものを 用いたときの $34 \%$ が最大であり, $\mathrm{Cl}^{-}$系では処理温度によらず数\%であった.

以上の結果について，これまでに報告された LDH の酸/塩基特性からの検討を加えた結果，ベンジ ル化の促進に層間イオンの塩基作用とともに基本層の Lewis 酸としての作用の関与が示唆された.

\section{1 緒言}

層状複水酸化物 (以下, LDH と略記する.) は, 一価あるいは二 価金属イオンと三価金属イオンの複水酸化物の層と層間の交換可 能な陰イオンおよび水分子とからなる積層構造を有する不定比化 合物であり, 次の組成式で表される ${ }^{1)}$.

$\left[\mathrm{M}_{1-x}^{z+} \mathrm{M}_{x}^{3+}(\mathrm{OH})_{2}\right]^{a+}\left[\mathrm{A}_{a / n}^{n-} \cdot y \mathrm{H}_{2} \mathrm{O}\right]$

$Z$ の值が 2 の場合, $a=x$ であり, $Z$ の值が 1 の場合は, $a=2 x-$ 1 である. $\mathrm{A}^{n-}$ は $n$ 価の陰イオンである.

従来から，液相有機反応において無機固体を酸，塩基として反 応性や選択性を高める研究が多く試みられている22-4). 層状化合 物では，モンモリロナイトに代表されるスメクタイト粘土鉱物が 多価金属イオンでイオン交換することによって強いブレンステッ ド酸性が発現することから，固体酸として多くの反応で活発に利 用されてきた225). スメクタイト粘土鉱物に比べると少ないが， 最近になって LDH についても, 酸/塩基特性に関する新たな事 実が見いだされ，液相有機反応に抢ける触媒あるいは反応促進媒 体としての利用の可能性が示されている，例えば， $\mathrm{CO}_{3}{ }^{2-}$ のよう に塩基性の強いイオンを層間に持つ $\mathrm{Mg}^{2+}-\mathrm{Al}^{3+} \mathrm{LDH}$ が，2-メ チル-3-ブチン-2-オール(以下, $\mathrm{MBOH}$ と略記する.)転化反応 に対してアルドール縮合や重合反応の塩基触媒として知られてい るこの LDH を焼成して得られる金属酸化物より優れた活性を示 すことが Pinnavaia ら ${ }^{6 / 7)}$ によって報告されている．著者ら8) も， さきに液相有機反応に㧍ける LDH の層間イオンの塩基性に由来 する反応促進媒体としての特性を明らかにする目的で, トルエン を溶媒とする安息香酸およびフェノールの1-ブロモブタンによ るブチル化に対する反応促進効果を調べ, $\mathrm{CO}_{3}{ }^{2-}$ や $\mathrm{OH}^{-}$のよう

東海大学理学部化学科, 259-1292 平塚市北金目 1117
に塩基性の強いイオンを層間イオンとする $\mathrm{Mg}^{2+}-\mathrm{Al}^{3+} \mathrm{LDH}$ の 共存によって, アルキル化が著しく促進することを見いだした. また，これらの LDH に安息香酸を作用させると安息香酸イオン としての層間侵入が認められたことから，反応の促進が層間イオ

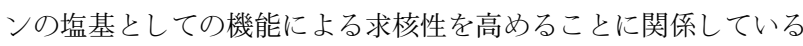
ことを明らかにした。

一方, $\mathrm{LDH}$ では層間イオンに基づいた塩基性のほか, 基本層 結晶の端表面は酸を形成している可能性があり，層間の陰イオン の塩基としての機能と基本層端表面の酸機能の協奏的反応促進作 用が期待される. アルコールのベンジル化は，一般に KOH のよ うな強塩基が用いられるが，弱い酸点と塩基点を共有するアルカ リ金属イオン交換 $\mathrm{Y}$ 型ゼオライトが，酸点と塩基点の共同作用 によって著しく促進することが明らかにされている ${ }^{9)}$ そここで， 本研究ではベンジルアルコールの臭化ベンジルによるベンジル化 反応 (式 (1)) を取り上げ, 各種 $\mathrm{LDH}$ の反応促進効果を調べた. なお， $\mathrm{LDH}$ としては， $\mathrm{CO}_{3}{ }^{2-}$ あるいは $\mathrm{Cl}^{-}$を層間イオンとする $\mathrm{Li}^{+}-\mathrm{Al}^{3+}$ 系抢よび $\mathrm{Mg}^{2+}-\mathrm{Al}^{3+}$ 系を用いた。

\section{2 実験}

\subsection{LDH の調製}

2.1.1 $\mathrm{Mg}^{2+}-\mathrm{Al}^{3+}-\mathrm{CO}_{3}{ }^{2-} \mathrm{LDH}$ : Miyata らの方法 ${ }^{10)}$ に準じ前 報8) と同様の方法で調製した。 $0.2 \mathrm{M}\left(1 \mathrm{M}=1 \mathrm{~mol} \mathrm{dm}{ }^{-3}\right) \mathrm{Na}_{2} \mathrm{CO}_{3}$ 水溶液 $0.5 \mathrm{dm}^{3}$ を含むビーカーに, $\left(\mathrm{Mg}^{2+} / \mathrm{Al}^{3+}\right)$ モル比 $=3$ に調 整した $0.8 \mathrm{M}$ の $\mathrm{Mg}\left(\mathrm{NO}_{3}\right)_{2}$ と $\mathrm{Al}\left(\mathrm{NO}_{3}\right)_{3}$ の混合水溶液を $\left(\mathrm{CO}_{3}{ }^{2-} /\right.$ $\left.\mathrm{Al}^{3+}\right)=0.7$ となる屯で滴下した。この際，反応液の $\mathrm{pH} を 10$ に 保つために $1 \mathrm{M}$ 水酸化ナトリウム水溶液を同時に滴下した. 固

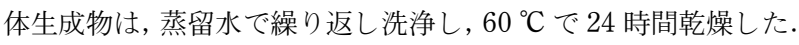

2.1.2 $\mathrm{Mg}^{2+}-\mathrm{Al}^{3+}-\mathrm{Cl}^{-} \mathrm{LDH}: \mathrm{Mg}^{2+}$ と $\mathrm{Al}^{3+}$ の試薬としてそ れぞれ塩化物を用い，Miyata らの方法 ${ }^{10)} に$ 準じ調製した。脱炭 
酸水 $0.5 \mathrm{dm}^{3}$ を含む三つロフラスコに, $\mathrm{N}_{2}$ 流通下, $\mathrm{CO}_{3}{ }^{2-}$ 系と 同じ $\left(\mathrm{Mg}^{2+} / \mathrm{Al}^{3+}\right)$ モル比に調整した $0.8 \mathrm{M}$ の $\mathrm{MgCl}_{2}$ と $\mathrm{AlCl}_{3}$ の 混合溶液と $1 \mathrm{M}$ 水酸化ナトリウム水溶液を同時に滴下した。滴 下終了後, $60{ }^{\circ} \mathrm{C}$ で 1 時間攪拌を続けた。 得られた固体生成物 は, 脱炭酸水で繰り返し洗浄し, $\mathrm{CO}_{3}{ }^{2-}$ 系と同様に $60{ }^{\circ} \mathrm{C} て ゙ 24$ 時間乾燥した。

2.1.3 $\mathrm{Li}^{+}-\mathrm{Al}^{3+}-\mathrm{CO}_{3}{ }^{2-} \mathrm{LDH}$ : Chisem らによって用いられて いる方法 ${ }^{11) 12)}$ で調製した。 $0.4 \mathrm{M}$ の $\mathrm{AlCl}_{3}$ 水溶液 $250 \mathrm{~mL}$ を 1.5 $\mathrm{M} \mathrm{LiOH}$ と $0.08 \mathrm{M} \mathrm{Na}_{2} \mathrm{CO}_{3}$ の混合水溶液 $600 \mathrm{~mL}$ に激しく攪拌

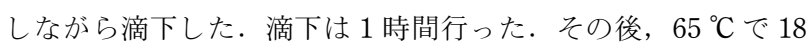
時間攪拌しながら保持した後, 固体生成物を数回水洗いし， 60 ${ }^{\circ} \mathrm{C}$ で 24 時間乾燥した.

2.1.4 $\mathrm{Li}^{+}-\mathrm{Al}^{3+}-\mathrm{Cl}^{-} \mathrm{LDH}:$ Dutta らによって用いられている 方法13) と同様の方法によった. アルミニウム $0.05 \mathrm{~mol}$ を $2 \mathrm{M}$ の $\mathrm{NaOH}$ 水溶液 $100 \mathrm{~mL}$ に溶解し, この水溶液に $\mathrm{LiCl} 0.25 \mathrm{~mol}$ を 溶解した. その後, 混合物を $\mathrm{N}_{2}$ 流通下, $90{ }^{\circ} \mathrm{C} て ゙ ~ 48$ 時間保持し た. 固体生成物は, $0.1 \mathrm{M} \mathrm{NaCl}$ 水溶液で洗浄し, $60{ }^{\circ} \mathrm{C} て ゙ 24$ 時 間乾燥した。

得られた各 $\mathrm{LDH}$ は, 粉末 $\mathrm{X}$ 線回折測定(理学電気侏製 $\mathrm{X}$ 線回 折装置 Geigerflex, $\mathrm{Cu}$ 対陰極, $40 \mathrm{kV}, 30 \mathrm{~mA}$ )により同定した.

\section{2 反応}

2.2.1 試薬: 反応試薬のベンジルアルコールおよび臭化ベン ジルは，いずれも市販の特級試薬をそのまま用いた。溶媒のトル エンは, 特級試薬を蒸留し, モレキュラーシーブ $4 \mathrm{~A}$ で乾燥し て用いた。

2.2.2 反応: ベンジルアルコールと臭化ベンジルの各 1 $\mathrm{mmol}$ とトルエン $20 \mathrm{~mL}$ を還流冷却管を付した $50 \mathrm{~mL}$ 丸底フラ スコにとり, LDH $0.5 \mathrm{~g}$ を加えて油浴上で 6 時間加熱, 攪拌し
た. 反応終了後, 反応混合物をガラス沪過器により沪過し, LDH は約 $10 \mathrm{~mL}$ のトルエンで洗浄し, 沪液と洗液を合わせてガ スクロマトグラフ (FID 検出器付き侏島津製作所製 GC-7A)によ り分析した。充填剤にはジーエルサイエンス陎製 Uniport HTを 用い, カラムには $3 \mathrm{~m}$ のガラスカラムを使用した.

生成物の同定は, 市販の純品とのガスクロマトグラフィーの保 持時間の比較により行った. 定量は, 酢酸ベンジルを用いて内部 標準法により行った.

\section{3 結果と考察}

Table 1 から 4 に $60-300{ }^{\circ} \mathrm{C}$ で加熱処理した $\mathrm{CO}_{3}{ }^{2-}$ あるいは $\mathrm{Cl}^{-}$を層間イオンとする $\mathrm{Li}^{+}-\mathrm{Al}^{3+}$ および $\mathrm{Mg}^{2+}-\mathrm{Al}^{3+} \mathrm{LDH}$ 存在 下で行ったトルエン中でのベンジルアルコールと臭化ベンジルの 反応結果を示す。なお，反応生成物のジベンジルエーテルおよび 塩化ベンジルの収率は，すべて臭化ベンジルを基準として求め た。 なた，目的反応生成物のジベンジルエーテル生成の選択率 は，臭化ベンジル消費量に対するジベンジルエーテル生成量の比 として求めた. 加熱処理は, 排気下で 1 時間行った.

\section{$3.1 \mathrm{Li}^{+}-\mathrm{Al}^{3+}-\mathrm{CO}_{3}{ }^{2-} \mathrm{LDH}$}

ベンジルアルコールと臭化ベンジルのそれぞれ $1 \mathrm{mmol}$ を含む トルエン溶液を 40 時間加熱, 攪拌したが反応生成物は全く認め られなかった.しかし, $60{ }^{\circ} \mathrm{C}$ で乾燥した $\mathrm{Li}^{+}-\mathrm{Al}^{3+}-\mathrm{CO}_{3}{ }^{2-} \mathrm{LDH}$ の $0.5 \mathrm{~g}$ を添加して同様に加熱, 攪拌した結果, 6 時間の反応で ベンジル化生成物のジベンジルエーテルが $54 \%$ の収率で得られ, $\mathrm{Li}^{+}-\mathrm{Al}^{3+}-\mathrm{CO}_{3}{ }^{2-} \mathrm{LDH}$ がベンジルアルコールの臭化ベンジルに よるベンジル化(式 (1))を促進することがわかった.

$\mathrm{PhCH}_{2} \mathrm{OH}+\mathrm{PhCH}_{2} \mathrm{Br} \longrightarrow \mathrm{PhCH}_{2} \mathrm{OCH}_{2} \mathrm{Ph}+\mathrm{HBr}$ (1)

この $60{ }^{\circ} \mathrm{C}$ で乾燥したものを用いた反応で認められた生成物は,

Table 1 The reaction of benzyl alcohol with benzyl bromide in presence of $\mathrm{Li}^{+}-\mathrm{Al}^{3+} \mathrm{LDH}$ containing $\mathrm{CO}_{3}{ }^{2-}$ in toluene ${ }^{\mathrm{a})}$

\begin{tabular}{ccccc}
\hline $\begin{array}{c}\text { Treated } \\
\text { temp } /{ }^{\circ} \mathrm{C}\end{array}$ & $\begin{array}{c}\text { Dibenzyl ether yieldb) } \\
\left(\text { selectivity }^{\mathrm{c}}\right) / \%\end{array}$ & $\begin{array}{c}\text { Benzyl alcohol } \\
\text { recovery } / \%\end{array}$ & $\begin{array}{c}\text { Benzyl bromide } \\
\text { recovery } / \%\end{array}$ & $\begin{array}{c}\text { Material } \\
\text { balance } / \%\end{array}$ \\
\hline 60 & $54(54)$ & 86 & 0 & 97 \\
150 & $80(80)$ & 29 & 0 & 95 \\
200 & $93(93)$ & 4 & 0 & 95 \\
250 & $27(90)$ & 52 & 70 & 88 \\
\hline
\end{tabular}

a) Reaction conditions: LDH $0.5 \mathrm{~g}$, benzyl alcohol $1 \mathrm{mmol}$, benzyl bromide $1 \mathrm{mmol}$, toluene $20 \mathrm{~mL}$, reaction time $6 \mathrm{~h}$, reflux.

b) Amount of products formed per initial amount of benzyl bromide.

c) Amount of dibenzyl ether formed per amount of benzyl bromide consumed.

Table 2 The reaction of benzyl alcohol with benzyl bromide in presence of $\mathrm{Li}^{+}-\mathrm{Al}^{3+} \mathrm{LDH}$ containing $\mathrm{Cl}^{-}$in toluene ${ }^{\text {a) }}$

\begin{tabular}{cccccc}
\hline $\begin{array}{c}\text { Treated } \\
\text { temp } /{ }^{\circ} \mathrm{C}\end{array}$ & $\begin{array}{c}\text { Dibenzyl ether yield } \\
\left(\text { (selectivity }^{\mathrm{c}}\right) / \%\end{array}$ & $\begin{array}{c}\text { Benzyl chloride } \\
\text { yield } / \%\end{array}$ & $\begin{array}{c}\text { Benzyl alcohol } \\
\text { recovery } / \%\end{array}$ & $\begin{array}{c}\text { Benzyl bromide } \\
\text { recovery } / \%\end{array}$ & $\begin{array}{c}\text { Material } \\
\text { balance } / \%\end{array}$ \\
\hline 60 & $72(72)$ & 4 & 35 & 0 & 92 \\
150 & $78(80)$ & 6 & 22 & 3 & 94 \\
200 & $59(78)$ & 8 & 34 & 24 & 92 \\
250 & $20(65)$ & 12 & 64 & 69 & 93 \\
\hline
\end{tabular}

a) Reaction conditions: LDH $0.5 \mathrm{~g}$, benzyl alcohol $1 \mathrm{mmol}$, benzyl bromide $1 \mathrm{mmol}$, toluene $20 \mathrm{~mL}$, reaction time $6 \mathrm{~h}$, reflux.

b) Amount of products formed per initial amount of benzyl bromide.

c) Amount of dibenzyl ether formed per amount of benzyl bromide consumed. 
Table 3 The reaction of benzyl alcohol with benzyl bromide in presence of $\mathrm{Mg}^{2+}-\mathrm{Al}^{3+} \mathrm{LDH}$ containing $\mathrm{CO}_{3}{ }^{2-}$ in toluene ${ }^{\mathrm{a})}$

\begin{tabular}{ccccc}
\hline $\begin{array}{c}\text { Treated } \\
\text { temp } /{ }^{\circ} \mathrm{C}\end{array}$ & $\begin{array}{c}\text { Dibenzyl ether yield b) } \\
(\text { selectivity }) / \%\end{array}$ & $\begin{array}{c}\text { Benzyl alcohol } \\
\text { recovery/\% }\end{array}$ & $\begin{array}{c}\text { Benzyl bromide } \\
\text { recovery } / \%\end{array}$ & $\begin{array}{c}\text { Material } \\
\text { balance/\% }\end{array}$ \\
\hline 60 & $4(4)$ & 146 & 0 & 77 \\
150 & $17(18)$ & 107 & 6 & 74 \\
200 & $29(47)$ & 60 & 43 & 81 \\
250 & $34(81)$ & 50 & 43 & 81 \\
300 & $28(68)$ & 63 & 53 & 86 \\
\hline
\end{tabular}

a) Reaction conditions: LDH $0.5 \mathrm{~g}$, benzyl alcohol $1 \mathrm{mmol}$, benzyl bromide $1 \mathrm{mmol}$, toluene $20 \mathrm{~mL}$, reaction time $6 \mathrm{~h}$, reflux.

b) Amount of products formed per initial amount of benzyl bromide.

c) Amount of dibenzyl ether formed per amount of benzyl bromide consumed.

Table 4 The reaction of benzyl alcohol with benzyl bromide in presence of $\mathrm{Mg}^{2+}-\mathrm{Al}^{3+} \mathrm{LDH}$ containing $\mathrm{Cl}^{-}$in toluenea

\begin{tabular}{cccccc}
\hline $\begin{array}{c}\text { Treated } \\
\text { temp } /{ }^{\circ} \mathrm{C}\end{array}$ & $\left.\begin{array}{c}\text { Dibenzyl ether yield } \\
\left(\text { selectivity }^{\mathrm{c}}\right)\end{array}\right)^{\circ}$ & $\begin{array}{c}\text { Benzyl chloride } \\
\text { yield }) / \%\end{array}$ & $\begin{array}{c}\text { Benzyl alcohol } \\
\text { recovery } / \%\end{array}$ & $\begin{array}{c}\text { Benzyl bromide } \\
\text { recovery } / \%\end{array}$ & $\begin{array}{c}\text { Material } \\
\text { balance } / \%\end{array}$ \\
\hline 60 & $6(6)$ & 63 & 84 & 6 & 83 \\
150 & $5(5)$ & 82 & 48 & 4 & 72 \\
200 & $4(4)$ & 80 & 55 & 4 & 74 \\
250 & $4(4)$ & 75 & 53 & 4 & 70 \\
300 & $2(2)$ & 64 & 68 & 9 & 73 \\
\hline
\end{tabular}

a) Reaction conditions: LDH $0.5 \mathrm{~g}$, benzyl alcohol $1 \mathrm{mmol}$, benzyl bromide $1 \mathrm{mmol}$, toluene $20 \mathrm{~mL}$, reaction time $6 \mathrm{~h}$, reflux.

b) Amount of products formed per initial amount of benzyl bromide.

c) Amount of dibenzyl ether formed per amount of benzyl bromide consumed.

ジベンジルエーテルのみであったが，ジベンジルエーテル生成量 の臭化ベンジル消費量に対する比として求めたジベンジルエーテ ル生成の選択率は 54\% と小さい。これに加え，一方の反応基質 のベンジルアルコールが，ジベンジルエーテル生成に消費された 分を差し引くと添加量の $40 \%$ 近く過剩に回収された．このこと は, ベンジル化に併発して臭化ベンジルの加水分解(式 (2))が 進行したことを示している.

$\mathrm{PhCH}_{2} \mathrm{Br}+\mathrm{H}_{2} \mathrm{O} \longrightarrow \mathrm{PhCH}_{2} \mathrm{OH}+\mathrm{HBr}$

$60{ }^{\circ} \mathrm{C}$ 乾燥のものを $150{ }^{\circ} \mathrm{C}$ あるい $200{ }^{\circ} \mathrm{C} て ゙$ 加熱処理して用 いたところ，ジベンジルエーテル収率は $60{ }^{\circ} \mathrm{C}$ 乾燥の $54 \%$ か ら，それぞれ 80\%抢よび 93\%に著しく増大した. Pinnavaia ら 7 ) は, $\mathrm{MBOH}$ の転化反応を指標反応として塩基強度の異なる各種 陰イオンを層間イオンとする $\mathrm{Mg}^{2+}-\mathrm{Al}^{3+} \mathrm{LDH}$ の塩基性につい て詳細な検討を行っている，そこでは， $\mathrm{CO}_{3}{ }^{2-}$ を層間イオンとす る LDH が塩基触媒として優れた活性を有するとともに，LDH の塩基性への層間 $\mathrm{CO}_{3}{ }^{2-}$ の寄与が示唆されている. $\mathrm{Li}^{+}-\mathrm{Al}^{3+}$ 系 では, $\mathrm{MBOH}$ 転化反応に対する挙動は明らかでないが, Chisem ら ${ }^{11)}$ によろメット指示薬法を用いた測定結果によると， $\mathrm{Li}^{+}$ $\mathrm{Al}^{3+}$ 系も $\mathrm{Mg}^{2+}-\mathrm{Al}^{3+}$ 系と同様に $\mathrm{H}_{0} \geqq 12$ の強い強度の塩基点を 持つ.これより, $\mathrm{Li}^{+}-\mathrm{Al}^{3+}-\mathrm{CO}_{3}{ }^{2-} \mathrm{LDH}$ のベンジル化の促進に は, 層間 $\mathrm{CO}_{3}{ }^{2-}$ の塩基としての作用が強く関与していると考え られる. 低温で処理したものを用いた際のベンジル化に併発して 起こる臭化ベンジルの加水分解によるベンジルアルコールの生成 も, 層間 $\mathrm{CO}_{3}{ }^{2-}$ の塩基作用によって層間にある水分子の求核性 が高められたことで起こると推定される. 加熱処理するとべンジ ル化反応への選択性が著しく増大するが，これは層間の水分子が
脱水されたことによる加水分解反応の抑制によると説明できる. さらに高温の $250{ }^{\circ} \mathrm{C}$ で処理すると, ジベンジルエーテル収率は,

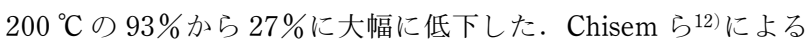
と, $\mathrm{Li}^{+}-\mathrm{Al}^{3+}-\mathrm{CO}_{3}{ }^{2-} \mathrm{LDH}$ は $225-245{ }^{\circ} \mathrm{C}$ を中心として $150-$ $370{ }^{\circ} \mathrm{C}$ の広い温度範囲で層間 $\mathrm{CO}_{3}{ }^{2-}$ と基本層表面ヒドロキシル 基の脱離が起こる。 また, Hernandez $ら^{14)}$ は, $200-1000{ }^{\circ} \mathrm{C}$ の 広範囲で分解によって $\gamma-\mathrm{LiAlO}_{2}$ と $\mathrm{LiAl}_{5} \mathrm{O}_{6}$ の複酸化物を生成す ると報告している。ここで用いた $250{ }^{\circ} \mathrm{C}$ 処理 $\mathrm{Li}^{+}-\mathrm{Al}^{3+}-\mathrm{CO}_{3}{ }^{2-}$ LDH では, 分解が進行している可能性が高く, この温度でのべ ンジル化に対する著しい活性低下は, 塩基として反応促進に寄与 している層間 $\mathrm{CO}_{3}{ }^{2-}$ の脱離によると説明できる.

一方, $250{ }^{\circ} \mathrm{C}$ 処理のものを用いた反応の場合, その反応液の ガスクロマトグラム上には保持時間が接近した二つのピークが新 たに見られた。これらのピークは，反応基質に臭化ベンジルのみ 用いた反応に抢いて生じたことから，臭化ベンジルと溶媒のトル エンの縮合(式 (3))によるベンジルトルエンと推定される.

$\mathrm{PhCH}_{2} \mathrm{Br}+\mathrm{PhCH}_{2} \mathrm{CH}_{3} \longrightarrow \mathrm{PhCH}_{2} \mathrm{C}_{6} \mathrm{H}_{4} \mathrm{CH}_{3}+\mathrm{HBr}$

このベンジルトルエンと推定される物質のガスクロマトグラム上 の二つのピークは, アルミナ存在下で臭化ベンジルとトルエンを 反応させた場合で顕著に見られた。そこで，この反応での反応液 を用いて ${ }^{1} \mathrm{H}-\mathrm{NMR} よ り$ 同定した. その結果, ベンジルトルエン に基づいたメチルプロトンによる $3 \mathrm{H}$ 分の吸収が $2.31 \mathrm{ppm}, 2 \mathrm{H}$ 分の吸収が $3.94 \mathrm{ppm}$ にそれぞれ一重線で, ベンゼン環の $9 \mathrm{H}$ 分 の吸収が $7.00-7.28 \mathrm{ppm}$ に多重線で認められた。 また, 2.24 $\mathrm{ppm}$ と $3.98 \mathrm{ppm}$ に $3 \mathrm{H}$ 分と $2 \mathrm{H}$ 分の吸収が一重線で認めら 
れ, ベンジルトルエンの二種類の異性体であることが確認され た.ここでベンジルトルエンを与えたことは, Friedel-Crafts 反 応に対して Lewis 酸として作用したことを示すが，その生成が 複酸化物への分解が進む $250{ }^{\circ} \mathrm{C}$ の高温で処理した場合であるこ と, また複酸化物は $\mathrm{MBOH}$ 転化反応において塩基とともに酸作 用による生成物を同時に与えることから ${ }^{9)}$ ，ここでの Lewis 酸と しての作用には分解によって生じた複酸化物が関係している可能 性が高い。

物質収支について見ると, 処理温度が $200{ }^{\circ} \mathrm{C}$ までのものを用 いた反応では $95 \%$ 以上の高い值を示した。しかし，ジベンジル エーテル収率の著しい低下が見られた $250{ }^{\circ} \mathrm{C}$ 処理の場合では 88 \%に低下した．この原因として，物質収支の算出に含めていない ベンジルトルエンの副生もあるが，ジベンジルエーテル収率から は 73\%近くのベンジルアルコールが回収されるべきであるが実 際は $52 \%$ と大幅に低いことから，ベンジルアルコールの LDH への吸着が強く関係していると推定される. 実際に $250{ }^{\circ} \mathrm{C}$ 処理 $\mathrm{Li}^{+}-\mathrm{Al}^{3+}-\mathrm{CO}_{3}{ }^{2-} \mathrm{LDH} 0.5 \mathrm{~g}$ をベンジルアルコール $1 \mathrm{mmol}$ を含 むトルエン溶液 $20 \mathrm{~mL}$ に加え, 反応と同様に加熱, 攪拌したと ころ, LDH が単位重量当たり $1.1 \mathrm{mmol}$ を吸着したことに相当 するベンジルアルコール濃度の減少が認められた. さらに, ベン ジルアルコールを作用させた後の LDH を室温で 30 分間, 真空 乾燥した後, $20 \mathrm{~mL}$ のトルエンに加えての加熱, 攪拌を繰り返 し行ったところ, 吸着量の $84 \%$ を回収するのに 9 回の反復を要 した。これらの事実は, $250{ }^{\circ} \mathrm{C}$ 処理 $\mathrm{Li}^{+}-\mathrm{Al}^{3+}-\mathrm{CO}_{3}{ }^{2-} \mathrm{LDH}$ がべ ンジルアルコールに対しては比較的大きな吸着能を有することを 示唆している. $\mathrm{Li}^{+}-\mathrm{Al}^{3+}-\mathrm{CO}_{3}{ }^{2-} \mathrm{LDH}$ の分解によって生成する 複酸化物は, $\mathrm{MBOH}$ 転化反応での反応選択性およびハメット指 示薬法での報告にあるように強い塩基性を有することから, 吸着 には分解によって生じた酸化物上の塩基点が関与していると考え られる.

一方, $\mathrm{Mg}^{2+}-\mathrm{Al}^{3+}$ 系のようにベンジル化に低活性な LDH で は, 複酸化物を形成しない $200^{\circ} \mathrm{C}$ 以下の処理温度においても物 質収支が低い。この場合もベンジルアルコールの LDH への吸着 が関与していると考えられるので, $150{ }^{\circ} \mathrm{C}$ 処理の $\mathrm{Mg}^{2+}-\mathrm{Al}^{3+}$ $\mathrm{CO}_{3}{ }^{2-} \mathrm{LDH}$ についても先と同様の方法で吸着能を調べた。 その 結果, 単位重量当たり $0.94 \mathrm{mmol}$ の吸着が認められた。 また, 吸着後の LDH を真空乾燥した後, トルエン中で還流したところ, 1 回の操作で吸着ベンジルアルコールの $48 \%$ が回収された．し かしながら, $250{ }^{\circ} \mathrm{C}$ 処理 $\mathrm{Li}^{+}-\mathrm{Al}^{3+}-\mathrm{CO}_{3}{ }^{2-} \mathrm{LDH}$ の場合とは違っ て 2 回目でベンジルアルコールの液相への溶出は全く認められ なかった. 回収量が大幅に低下したのは, 真空乾燥時に脱離した ためと考えられ，層状構造を保持している間の LDHへのベンジ ルアルコール吸着は, 高温処理のそれに比べて弱いことを示して いる. その吸着席については後述した。

\section{$3.2 \mathrm{Li}^{+}-\mathrm{Al}^{3+}-\mathrm{Cl}^{-} \mathrm{LDH}$}

$60{ }^{\circ} \mathrm{C}$ 乾燥および $150{ }^{\circ} \mathrm{C}$ 加熱処理のものを用いた反応におい て, それぞれ $72 \%, 78 \%$ の収率でジベンジルエーテルが生成し ており，層間イオンが $\mathrm{Cl}^{-}$の場合もベンジル化を促進すること が明らかとなった。しかしながら, 層間イオンが $\mathrm{CO}_{3}{ }^{2-}$ の場合 とは, 幾つかの点で相違が認められた.

まず， $\mathrm{Cl}^{-}$系でも低温で処理したものでは，臭化ベンジルの加 水分解反応を併発するが，ここで生じたベンジルアルコールは
$\mathrm{CO}_{3}{ }^{2-}$ 系に比べるとかなり少ない。例えば, $60{ }^{\circ} \mathrm{C}$ 乾燥のものを 用いた反応では, $\mathrm{CO}_{3}{ }^{2-}$ 系が初めの添加量の $40 \%$ に相当する量 が過剰に回収されたのに対して, $\mathrm{Cl}^{-}$系を用いた際の過剩分は 4 \%であった。このことは, $\mathrm{Cl}^{-}$系の塩基機能は $\mathrm{CO}_{3}{ }^{2-}$ 系より劣 ることを示している. ハメット指示薬法では, $\mathrm{Li}^{+}-\mathrm{Al}^{3+}-\mathrm{Cl}^{-}$ $\mathrm{LDH}$ は $0.1 \leqq H_{0} \leqq 5.2$ の酸強度を持つことが報告されている ${ }^{11)}$. $\mathrm{Cl}^{-}$系も $200{ }^{\circ} \mathrm{C}$ 以上の高温で処理すると $\mathrm{CO}_{3}{ }^{2-}$ 系で見られたよ うにジベンジルエーテル収率の急激な低下が認められる. しかし, $\mathrm{Cl}^{-}$系は $\mathrm{CO}_{3}{ }^{2-}$ 系に比べ熱的安定性は高く, ここで調べた処理 温度範囲では表面ヒドロキシル基の脱離や層構造の破壊が起こる 可能性は低い。一方, $\mathrm{Li}^{+}-\mathrm{Al}^{3+}-\mathrm{Cl}^{-} \mathrm{LDH}$ はさきに述べたよう に $0.1 \leqq H_{0} \leqq 5.2$ の酸強度を示すが， $400{ }^{\circ} \mathrm{C}$ で焼成すると $4.2 \leqq$

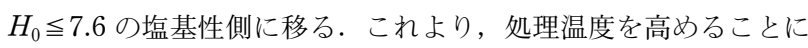
よる活性低下は, 酸強度の低下に関係していると考えられる，以 上のことから, $\mathrm{Li}^{+}-\mathrm{Al}^{3+}-\mathrm{Cl}^{-} \mathrm{LDH}$ のベンジル化促進には, $\mathrm{CO}_{3}{ }^{2-}$ 系とは違って酸としての機能がより強く関与していると考 えられる. $\mathrm{CO}_{3}{ }^{2-}$ 系では $250{ }^{\circ} \mathrm{C}$ 処理のもので認められた Friedel -Crafts 反応生成物のベンジルトルエンが, $\mathrm{Cl}^{-}$系では $60{ }^{\circ} \mathrm{C}$ 乾 燥のものから認められた。このことも， $\mathrm{Cl}^{-}$系のベンジル化の促 進には，酸機能が関与していることを示唆している.

$\mathrm{Cl}^{-}$系では反応生成物としてジベンジルエーテル, ベンジルト ルエンとともに，層間 $\mathrm{Cl}^{-}$と臭化ベンジルのハロゲン置換反 応 ${ }^{15) 16)}($ 式 (4))による塩化ベンジルが認められた.

$$
\begin{aligned}
& \mathrm{Li}^{+}-\mathrm{Al}^{3+}-\mathrm{Cl}^{-} \mathrm{LDH}+\mathrm{PhCH}_{2} \mathrm{Br} \longrightarrow \\
& \mathrm{Li}^{+}-\mathrm{Al}^{3+}-\mathrm{Br}^{-} \mathrm{LDH}+\mathrm{PhCH}_{2} \mathrm{Cl}
\end{aligned}
$$

この反応による塩化ベンジルの収率は， $60-250{ }^{\circ} \mathrm{C}$ の間で処理 温度の上昇に伴って $4 \%$ から $12 \%$ に増大した. $60{ }^{\circ} \mathrm{C}$ 乾燥の場合, $\mathrm{Cl}^{-}$系が $\mathrm{CO}_{3}{ }^{2-}$ 系より高収率でジベンジルエーテルを与えたの に対して，最大収率が $\mathrm{CO}_{3}{ }^{2-}$ 系の $93 \%$ より $15 \%$ ほど低くなった のは, 置換反応によって生成した塩化ベンジルの反応性が低いこ とも関係している．この点を確認するために塩化ベンジルについ て $150{ }^{\circ} \mathrm{C}$ 処理のものを用いて行った結果, 同様の反応条件でシ ベンジルエーテル収率は $34 \%$ であり, 臭化ベンジルを用いた際 の半分以下であった.

\section{$3.3 \mathrm{Mg}^{2+}-\mathrm{Al}^{3+}-\mathrm{CO}_{3}^{2-} \mathrm{LDH}$}

60-150 ${ }^{\circ} \mathrm{C}$ 処理のものを用いた反応では, $\mathrm{Li}^{+}-\mathrm{Al}^{3+}$ 系と同様 に $94 \%$ 以上の臭化ベンジルが転化した。しかし, 主反応生成物 は臭化ベンジルの加水分解によるベンジルアルコールであり, ベ ンジル化反応への選択性は同じ $\mathrm{CO}_{3}{ }^{2-}$ を層間イオンとした $\mathrm{Li}^{+}$ $\mathrm{Al}^{3+}$ 系に比べてかなり低い。例えば， $60^{\circ} \mathrm{C}$ 乾燥のものを用いた 反応では，ジベンジルエーテル収率がわずかに $4 \%$ であるのに 対して, ベンジルアルコールは初めに添加した量の約 1.5 倍量が 回収された。 また，物質収支が $77 \%$ と低くなった分を LDHに 吸着したベンジルアルコールと考えると, 加水分解によって生成 したベンジルアルコールは $0.9 \mathrm{mmol}$ に相当する．このように 60 ${ }^{\circ} \mathrm{C}$ 乾燥のものにおいてベンジル化反応への選択性が著しく低い ことは, $\mathrm{Mg}^{2+}-\mathrm{Al}^{3+}$ 系がベンジル化に対して低活性であること を示している.この LDH の場合も処理温度を高めると, 層間水 の脱水によって加水分解反応が抑制され，ベンジル化反応への選 択性は高くなるが，ベンジルエーテル収率は最大でも $250{ }^{\circ} \mathrm{C}$ 処 理のものを用いた際の $34 \%$ であった。このことも $\mathrm{Mg}^{2+}-\mathrm{Al}^{3+}$ $\mathrm{CO}_{3}{ }^{2-} \mathrm{LDH}$ がベンジル化に低活性であることを示している.な 
お， $250{ }^{\circ} \mathrm{C}$ 処理のものを用いて反応時間の延長を試みた結果, 12 時間の反応でジベンジルエーテル収率は $85 \%$ に増大した。こ れより, $\mathrm{Li}^{+}-\mathrm{Al}^{3+}$ 系より活性は低いがベンジル化を促進する機 能を持つことがわかった。 なお，この LDHにおいても，200 ${ }^{\circ} \mathrm{C}$ 処理のものから, Friedel-Crafts 反応生成物のベンジルトルエン が認められた.

さきに述べたように, $150{ }^{\circ} \mathrm{C}$ 以下で処理した $\mathrm{Mg}^{2+}-\mathrm{Al}^{3+}$ $\mathrm{CO}_{3}{ }^{2-} \mathrm{LDH}$ は, $\mathrm{MBOH}$ 転化反応に抢いて塩基として優れた活 性を示す。 また，八メット指示薬法による測定でも， $\mathrm{Li}^{+}-\mathrm{Al}^{3+}$ $\mathrm{CO}_{3}{ }^{2-} \mathrm{LDH}$ と同様に $H_{0} \geqq 12$ の強い塩基点を持つことが報告さ れている.しかし，ベンジル化に対する促進効果は, $\mathrm{Li}^{+}-\mathrm{Al}^{3+}$ 系より大幅に小さい，このようにベンジル化の促進に基本層を構 成する金属イオンの種類によって顕著な差を生じたことは, ベン ジル化には層間イオンの塩基作用ばかりでなく，基本層構成金属 イオンに基づいた酸としての機能が関与していることを示唆して いる.

\section{$3.4 \mathrm{Mg}^{2+}-\mathrm{Al}^{3+}-\mathrm{Cl}^{-} \mathrm{LDH}$}

さきの $\mathrm{Li}^{+}-\mathrm{Al}^{3+}-\mathrm{Cl}^{-} \mathrm{LDH}$ の場合では, 求核置換反応に比べ ベンジル化反応への選択性が高く, 高収率でジベンジルエーテル を与えた。これに対して, 基本層構成金属イオンが $\mathrm{Mg}^{2+}-\mathrm{Al}^{3+}$ の系では, $60{ }^{\circ} \mathrm{C}$ 乾燥のものから $300{ }^{\circ} \mathrm{C}$ 処理のものまで, 求核置 換反応による塩化ベンジルを $63-82 \%$ の高収率で生成し，ジベ ンジルエーテルの収率は $6 \%$ 以下であった．さらに反応時間を 40 時間に延長しても, ジベンジルエーテル収率の増加は見られ ず，本 $\mathrm{LDH}$ が本質的にベンジル化反応への促進機能を有してい ないことが示された，なお，この反応での反応生成物は，塩化べ ンジルとジベンジルエーテルのみで, ベンジルトルエンは認めら れなかった． $\mathrm{Mg}^{2+}-\mathrm{Al}^{3+}-\mathrm{Cl}^{-} \mathrm{LDH}$ は， $\mathrm{MBOH}$ 転化反応に扮い ても塩基として作用する. しかし，その活性は $\mathrm{CO}_{3}{ }^{2-}$ に比べる とかなり低い。例えば, $150{ }^{\circ} \mathrm{C} て ゙$ 加熱処理したものを用いた際 の反応温度 $80{ }^{\circ} \mathrm{C}$ での速度定数を比較すると, $\mathrm{CO}_{3}{ }^{2-}$ 系が 0.024 $\mathrm{mmol} / \mathrm{h} \mathrm{m}^{2}$ に対して $\mathrm{Mg}^{2+}-\mathrm{Al}^{3+}-\mathrm{Cl}^{-}$は $0.006 \mathrm{mmol} / \mathrm{h} \mathrm{m}^{2}$ とか なり小さい，このことからも明らかなように $\mathrm{Cl}^{-}$系の塩基とし ての機能は $\mathrm{CO}_{3}{ }^{2-}$ 系に比べて劣る. 一方, ハメット指示薬法で は酸点の存在が報告されているが, $\mathrm{Li}^{+}-\mathrm{Al}^{3+}$ 系は $H_{0} \leqq 4.2$ の酸 点を持つのに対して, $\mathrm{Mg}^{2+}-\mathrm{Al}^{3+}$ 系は $H_{0} \leqq 5.2$ であり酸性は弱 い.ここでの結果は, これらの特性に対応している.

以上, $\mathrm{CO}_{3}{ }^{2-}$ あるいは $\mathrm{Cl}^{-}$を層間イオンとする $\mathrm{Li}^{+}-\mathrm{Al}^{3+}$ 打よ び $\mathrm{Mg}^{2+}-\mathrm{Al}^{3+}$ 系の 4 種の $\mathrm{LDH}$ 上でのベンジルアルコールと臭 化ベンジルの反応を行った結果, 次の傾向が認められた.

（1）層間イオンが塩基性の強い $\mathrm{CO}_{3}{ }^{2-}$ の場合には，基本層構 成イオンが $\mathrm{Li}^{+}-\mathrm{Al}^{3+}$ の系, $\mathrm{Mg}^{2+}-\mathrm{Al}^{3+}$ の系ともにベンジル化を 促進する.

（2）層間イオンが塩基性の弱い $\mathrm{Cl}^{-}$の場合, $\mathrm{Li}^{+}-\mathrm{Al}^{3+}$ 系は促 進するが, $\mathrm{Mg}^{2+}-\mathrm{Al}^{3+}$ 系はほとんど促進しない.

著者ら ${ }^{8)}$ は, さきに $\mathrm{CO}_{3}{ }^{2-}$ や $\mathrm{OH}^{-}$のように塩基性の強いイオ ンを層間に持つ $\mathrm{Mg}^{2+}-\mathrm{Al}^{3+} \mathrm{LDH}$ は, トルエン中で安息香酸を 作用させると層間イオンの塩基作用により安息香酸分子を強く分 極し, 安息香酸イオンとして層間浸入させることを基本層層間距 離 $\left(d_{003}\right)$ の拡張抢よび赤外吸収スペクトルから示した. ベンジル アルコールについても層間浸入の可能性を明らかにするために, $\mathrm{Mg}^{2+}-\mathrm{Al}^{3+}-\mathrm{CO}_{3}{ }^{2-} \mathrm{LDH}$ のベンジルアルコール吸着による基本
層層間距離の变化を $\mathrm{X}$ 線回折より調べた。なお, ベンジルアル コール吸着は，3.1に述べた方法によった．また，同様の方法で 乾燥してX 線回折測定に供した。測定の結果, ベンジルアル コールを吸着した $\mathrm{Mg}^{2+}-\mathrm{Al}^{3+}-\mathrm{CO}_{3}{ }^{2-} \mathrm{LDH}$ は, ブランクとして 行ったトルエン中で還流したものより 1.8 倍近く大きな半值幅の ブロードな (003) 回折ピークを与えた。 また，このブロードな (003) 回折ピークの面間隔 $d_{003}$ の值は, ブランクのそれより 0.2 $\AA$ 大きくなった. $\mathrm{LDH} へ$ へ陰イオンの層間浸入時では, 層間で の陰イオンの配列が十分に進まないと層間距離の不均一性によっ てピーク先端の分裂やピーク幅の増大が観察される. ベンジルア ルコール吸着によっても， $d_{003}$ の増大を伴って (003) 回折ピーク のピーク幅の増大が観察されたことは, ベンジルアルコール分子 も層間浸入することを示唆している．しかしながら， $d_{003}$ の増大 幅が安息香酸吸着時の $0.8 \AA$ に比べ小さいことから, ベンジルア ルコール分子の層間浸入は表面近傍の層間に限って起こると考え られる. 以上, 層間に $\mathrm{CO}_{3}{ }^{2-}$ を持つ $\mathrm{LDH}$ がベンジルアルコール 分子を層間浸入させることは, 層間 $\mathrm{CO}_{3}{ }^{2-}$ が塩基としてベンジ ルアルコールを分極している可能性を示すものであり，(1)の傾向 は層間 $\mathrm{CO}_{3}{ }^{2-}$ がベンジルアルコールの求核性を高めるのに寄与 していることを示唆している. 一方, 臭化ベンジルは $\mathrm{Zn}^{2+}$ $\mathrm{Cr}^{3+}-\mathrm{I}^{-} \mathrm{LDH}$ の層間 $\mathrm{I}^{-}$とハロゲン化アルキルとのハロゲン置換 反応の報告15)で結論されているように, 基本層端表面に吸着し ており，ベンジル化は基本層端表面に吸着した臭化ベンジルとそ の近傍の層間に吸着したベンジルアルコールとの反応によって進 行すると推定される. 臭化ベンジルの吸着サイトを供している基 本層端表面は，構成金属イオンの正電荷によって酸の発現部位と なる可能性が高い. 特に, プラスに荷電した基本層からなる LDH の基本層端表面は, 過剩な正電荷によって Lewis 酸性を形 成し，臭化ベンジルを分極し，その求電子性を高めるのに寄与す ると考えられる。したがって，(2)の基本層構成イオンによる活性 の相違は，臭化べンジルに対する Lewis 酸としての機能の差を 表すもので, $\mathrm{Li}^{+}-\mathrm{Al}^{3+}$ 系が $\mathrm{Mg}^{2+}-\mathrm{Al}^{3+}$ 系に比べより強く分極す る機能を持つことを示している，このことは， $\mathrm{Cl}^{-}$を層間に持つ $\mathrm{Li}^{+}-\mathrm{Al}^{3+}$ 系が層構造を保持している間から Friedel-Crafts 反応 生成物を与えたことからも説明できる.八メット法では酸の種類 までは言及されていないが，3.4 で述べたように $\mathrm{Li}^{+}-\mathrm{Al}^{3+}$ 系は $\mathrm{Mg}^{2+}-\mathrm{Al}^{3+}$ 系より強い酸のサイトが存在する.

以上のことから，ベンジルアルコールの臭化ベンジルによるべ ンジル化反応における反応促進には, 層間イオンの塩基としての 作用とともに基本層の Lewis 酸としての機能の関与が推定され た.

なお，ベンジル化反応とともに併発する副反応で生成する HBr は LDH に補足されている．この点でここで認められた反応 促進は触媒としてではなく, 反応促進剂としての作用によるとい える。

1) F. Cavani, F. Trifiro, A. Vaccari, Catal. Today, 11, 173 (1991).

2) 泉 有亮, 卜部 和夫, 尾中 篤, 触媒, 27,27 (1985).

3）尾中 篤, 泉 有亮, 有合化, 47, 233(1989).

4) 泉 有亮, 尾中 篤, 表面, 28,810(1990).

5）日本化学会編 “季刊化学総説 No. 21 マイクロポーラス. クリスタル”，学会出版センター(1994), p. 114.

6) R. L. Constantino, T. J. Pinnavaia, Catal. Lett., 1994, 361. 
7) R. L. Constantino, T. J. Pinnavaia, Inorg. Chem., 34, 883 (1995).

8）島田 紘, 濱岡 昌, 日化, 2000, 91 .

9) M. Onaka, M. Kawai, Y. Izumi, Bull. Chem. Soc. Jpn., 58 , 1764 (1986).

10) S. Miyata, Clays Clay Miner., 23, 369 (1975).

11) I. C. Chisem, W. Jones, I. Martin, C. Martin, V. Rives, J. Mater. Chem., 8, 1917(1998)
12) I. C. Chisem, W. Jones, J. Mater. Chem., 4, 1737 (1994).

13) P. K. Dutta, M. Puri, J. Phys. Chem., 93, 376(1989).

14) M. J. Hernandez, M. A. Ulibarri, J. Cornejo, M. J. Pena, C. J. Serna, Thermochim. Acta, 94, 257 (1985).

15) K. J. Martin, T. J. Pinnavaia, J. Am. Chem. Soc., 108, 541 (1986).

16) E. Suzuki, M. Okamoto, Y. Ono, J. Mol. Catal., 61, 283 (1990)

\title{
Benzylation of Benzyl Alcohol on Layered Double Hydroxides
}

\author{
Hiroshi SHIMADA* and Takashi SASANOMA \\ Department of Chemistry, School of Science, Tokai University; 1117 Kitakaname, \\ Hiratsuka-shi 259-1292 Japan
}

The effectiveness of $\mathrm{Li}^{+}-\mathrm{Al}^{3+}$ and $\mathrm{Mg}^{2+}-\mathrm{Al}^{3+}$ layered double hydroxide (LDH) intercalated with $\mathrm{CO}_{3}{ }^{2-}$ or $\mathrm{Cl}^{-}$as a reaction media for benzylation of benzyl alcohol with benzyl bromide in toluene was examined. Among a series of $\mathrm{LDHs}, \mathrm{Li}^{+}-\mathrm{Al}^{3+} \mathrm{LDH}$ was found to be effective. For instance, a reaction in the presence of $\mathrm{Li}^{+}-\mathrm{Al}^{3+}-\mathrm{CO}_{3}{ }^{2-}$ heat-treated at $200{ }^{\circ} \mathrm{C}$ gave the desired benzylated products in $93 \%$ yield by refluxing for $6 \mathrm{~h}$. Also, $\mathrm{Li}^{+}-\mathrm{Al}^{3+}-\mathrm{Cl}^{-}$heat- treated at $150{ }^{\circ} \mathrm{C}$ gave the benzylated product in 78 $\%$ yield for same conditions. In the case of $\mathrm{Mg}^{2+}-\mathrm{Al}^{3+} \mathrm{LDH}$, it is found that it possessed less activity, showing reduced yields $34 \%$ for containing $\mathrm{CO}_{3}{ }^{2-}$ and $2-6 \%$ for containing $\mathrm{Cl}^{-}$respectively. 